Cornell Law Library

Scholarship@Cornell Law: A Digital Repository

Cornell Law Faculty Publications

9-1-2008

\title{
The Dilemma of the Criminal Defendant with a Prior Record - Lessons from the Wrongfully Convicted
}

John H. Blume

Cornell Law School, john-blume@postoffice.law.cornell.edu

Follow this and additional works at: http://scholarship.law.cornell.edu/lsrp_papers

Part of the Criminal Law Commons

\section{Recommended Citation}

Blume, John H., "The Dilemma of the Criminal Defendant with a Prior Record - Lessons from the Wrongfully Convicted" (2008). Cornell Law Faculty Publications. Paper 83.

http://scholarship.law.cornell.edu/lsrp_papers/83

This Article is brought to you for free and open access by Scholarship@Cornell Law: A Digital Repository. It has been accepted for inclusion in Cornell Law Faculty Publications by an authorized administrator of Scholarship@Cornell Law: A Digital Repository. For more information, please contact jmp8@cornell.edu. 


\title{
The Dilemma of the Criminal Defendant with a Prior Record-Lessons from the Wrongfully Convicted
}

\author{
John H. Blume*
}

This article examines the conventional wisdom that innocent defendants will testify on their own behalf at trial. Data gathered from the cases of persons subsequently exonerated due to DNA evidence demonstrate that factually innocent defendants with criminal records do not testify on their own behalf at substantially higher rates than criminal defendants generally. Why? Ninety-one percent of factually innocent defendants with prior records declined to testify compared to the 55 percent rate at which defendants with prior criminal records declined to testify in a four-county sample of criminal cases. Why the difference? In the innocence cases, the primary reason counsel give for not taking the stand is that many of these individuals had been previously convicted of a crime, and they did not testify at trial because of the risk that their credibility would be impeached with evidence of the prior record, and that, despite any limiting instruction the court might give, the jury would infer that they were guilty based on their prior misdeeds. If one assumes that the defendants in a four-county sample are guilty, and that both the innocence sample and the four-county sample are reasonably representative, then there is a statistically significant association between defendants with criminal records failing to testify and innocence. Because the current legal regime appears to disproportionately discourage defendants, even factually innocent defendants, from telling their story at trial, the law should be changed. Only prior convictions for perjury should be potentially available for impeachment purposes.

*Professor of Law, Cornell Law School, 110 Myron Taylor Hall, Ithaca, NY 14853; email: jb94@cornell.edu.

I thank Erin Choi, Joanna Davella, Drucy Glass, Matthew Jury, Lei Young, and Amber Whitfield for their research and data-gathering assistance. I thank Steve Clymer, Sherry Colb, Ted Eisenberg, George Fischer, Steve Garvey, Sam Gross, Sheri Johnson, and Faust Rossi for their helpful suggestions and comments.

(C) 2008, Copyright the Author

Journal compilation @ 2008, Cornell Law School and Wiley Periodicals, Inc. 


\section{INTRODUCTION}

The conventional wisdom is that innocent defendants testify on their own behalf. Most people think: "If it were me, and I were charged with a crime I did not commit, I would put my hand on the Bible, get up on that witness stand, look those jurors dead in the eye, and tell them that I didn't do it. Only guilty people don't testify." "The conventional wisdom is wrong. Frederick Daye, for example, was charged with rape, kidnapping, and robbery. He filed a motion requesting that the trial judge prohibit the prosecution from impeaching him with a five-year-old robbery conviction. The trial judge denied the motion, and Daye elected not to testify. He was found guilty of all charges and sentenced to life in prison. On appeal, the California Court of Appeal upheld the trial judge's ruling. ${ }^{2}$ After serving 10 years in prison, a California court granted Daye's request for DNA testing. The results conclusively established Daye's innocence, and he was released. ${ }^{3}$

Daye's case is paradigmatic of the controversy surrounding rules of evidence permitting criminal defendants to be impeached with prior convictions. Many critics of impeachment have argued that such rules discourage defendants, even innocent ones, from testifying. Proponents of impeachment, on the other hand, argue that precluding or limiting the current rules will result in a flood of perjured testimony from guilty defendants liberated from their prior misdeeds. What has been largely missing from the debate are facts.

${ }^{1}$ Polling data indicate that approximately half of all Americans believe that a defendant who does not testify in his or her own defense is guilty. Survey by Fox News and Opinion Dynamics, February 12-13, 2002. Retrieved April 25, 2008 from the iPOLL Databank, The Roper Center for Public Opinion Research, University of Connecticut. The reality of a defendant's silence was described by Arthur Train in The Prisoner at the Bar as follows:

The law humanely provides that if a prisoner does not wish to testify his failure to do so shall not be taken against him by the jury. But does anyone imagine that a defendant is not usually obliged to testify if he expects to be acquitted? The very first thing we want to know about a person charged with crime is what explanation he has to make. If he refuses to make any, we know that he has none worth making.... Jurors have often said to me, regarding a defendant who did not take the stand, "Of course, we couldn't hold against him his failure to testify, but we knew he was guilty, because he was afraid to subject himself to cross-examination."

A. Arthur Train, The Prisoner at the Bar 212 (1923).

${ }^{2}$ People v. Daye, 222 Cal. Rptr. 614, 624-25 (1986).

${ }^{3}$ See $\langle$ http://www.innocenceproject.org/Content/83.php〉, accessed May 16, 2008. 
In an attempt to fill this empirical void, I examined the cases of individuals who were convicted of crimes that we now know, as a result of posttrial DNA testing, they did not commit. I discovered that Frederick Daye's case is not unique. Many of the wrongfully convicted defendants failed to testify. In fact, demonstrably innocent defendants do not testify in their own defense at substantially different rates than criminal defendants in general. But why? Why did these innocent defendants fail to take the witness stand and tell their stories?

The reasons vary: some of the defendants were slow or even mentally retarded; in other cases, the defense believed the case was weak, but the primary reason, as Frederick Daye's case reveals, is the fear of impeachment with their prior convictions. Virtually all the defendants who did not testify had a prior record that likely would have been disclosed to the jury had they taken the stand. These defendants believed, or their lawyers believed, that if the jury knew the defendant had previously committed another criminal offense, it would be more likely-despite the judge's instructions to the contrary-to conclude that the defendant is the type of person who would have done it. In the exoneration cases where a defendant with a prior record did testify, the court always permitted the prosecution to impeach the defendant. A number of the convictions used to impeach the defendant were for crimes identical or very similar to the charged offense. Thus, it is likely that the jury in those cases-despite a limiting instruction restricting the use of the conviction to assessing the defendant's credibility—drew the "forbidden" propensity inference. From these data, I conclude that the current rules of evidence contribute to wrongful convictions.

After first discussing the current legal landscape in Section II, I will present the empirical evidence in Section III. Although much has been written about factors leading to erroneous convictions, the literature has heretofore focused on other causes, including, for example, mistaken eyewitness identifications, "junk" science, false confessions, false testimony from jailhouse informants and cooperating witnesses, prosecutorial misconduct, and bad lawyering. ${ }^{4}$ This is the first empirical study to consider the effects a defendant's prior record may have in cases where we know for a fact that there was a breakdown in the criminal justice system. In Section IV, I offer several proposals for reform. In short, I propose that only prior convictions for perjury should be potentially available to the prosecution for impeach-

${ }^{4}$ See, e.g., Barry Scheck, Peter Neufeld \& Jim Dwyer, Actual Innocence (2000). 
ment purposes unless the defendant injects his or her good character into the case.

\section{The Current Legal Framework}

A defendant's right to testify in his or her own defense, though of relatively recent vintage compared to many other rights of an accused, is a hallmark of American criminal procedure. ${ }^{5}$ The Supreme Court has said that the right to "testify on one's behalf is '[a right] ... that is essential to due process of law in a fair adversary process." " ${ }^{6}$ In addition to permitting individuals accused of crimes to testify, the criminal justice system should encourage them to do so. After all, who has more information bearing directly on the defendant's guilt or innocence than the defendant himself or herself? ${ }^{7}$ Unfortunately, the current rules of evidence governing impeachment

\footnotetext{
${ }^{5}$ Rock v. Arkansas, 483 U.S. 44, 52, 53, n.10 (1987). For many years, a defendant could not be placed under oath and was not permitted to testify on his or her own behalf. See George Fisher, Plea Bargaining's Triumph (2003). Thus there was no expectation that defendants would testify. A concern that forbidding defendants from testifying on their own behalf could lead to the conviction of innocent persons was the primary reason leading to the recognition of a defendant's constitutional right to testify. Note, Procedural Protections of the Criminal Defendant-A Reevaluation of the Privilege Against Self-Incrimination and the Rule Excluding Evidence of Propensity to Commit Crime, 78 Harv. L. Rev. 426, 428 (1965). However, some scholars and judges noted that the regime change also changed juror expectations and left the defendant, especially one with prior convictions, with two "unpleasant alternatives." Fisher, supra, at 104. As one judge put it more than a hundred years ago: "First, [the defendant] could choose silence and face almost inevitable conviction." Id. This was so because jurors knew that the defendant could testify if he or she so chose and that the defendant would "if he dared." Id. "Yet if the defendant did as he must and took the stand, he faced a second unpleasant alternative: Those defendants who had criminal records would be "torn to pieces' by cross-examination." Id. Thus there were many who believed (and still believe) that allowing defendants to testify was, in the aggregate, harmful to their chances of acquittal. See, e.g., Roger C. Park, Impeachment with Evidence of Prior Convictions, 36 S.W.U. L. Rev. 793, 814 (2008).
}

${ }^{6}$ Id. at 51 (quoting Faretta v. California, 422 U.S. 806, 819, n.15 (1975)).

${ }^{7}$ Id. at 52 ("In fact, the most important witness for the defense in many criminal cases is the defendant himself. There is no justification today for a rule that denies an accused the opportunity to offer his own testimony."); Alan Hornstein, Between Rock and a Hard Place: The Right to Testify and Impeachment by Prior Conviction, 42 Vill. L. Rev. 1, 19 (1997) (if the defendant elects not to testify, the "factfinder will be denied the opportunity to hear from a witness who may have the best access to the facts embraced by the charge"). 
with prior convictions both discourage defendants with a prior criminal past from testifying, and even when defendants do testify, often contribute to their convictions. ${ }^{8}$

Let us begin with the less controversial and more entrenched antipropensity rule. ${ }^{9}$ The anti-propensity doctrine-in theory-forbids the prosecution from presenting evidence of the defendant's bad character. The admission of such evidence is thought to create a danger that the jury will punish the defendant for offenses other than those for which he or she is on trial and that it will convict, even when unsure of the defendant's guilt, because the defendant is a "bad person" who deserves to be punished. ${ }^{10}$ This general rule is reflected in Federal Rule of Evidence 404, which, for the most part, renders inadmissible "[e]vidence of a person's character or a trait of

\footnotetext{
${ }^{8}$ Some (but not many) courts have taken this into account in determining whether impeachment will be allowed. In United States v. Paige, 464 F. Supp. 99, 100-01 (E.D. Pa. 1978), the court believed that it was "especially important that the defendant feel free to testify and this ... weighs heavily against allowing the impeachment use of the prior conviction." After explaining how the facts and law of the case made the defendant's testimony critical to his defense, the court concluded that the "defense will be prejudiced severely if the [the defendant] is deterred from testifying from fear that he will be convicted on the basis of a prior crime. Therefore, justice requires that use of the prior conviction be disallowed unless the government shows strong justification.” Id.
}

${ }^{9}$ Richard Friedman, Character Impeachment Evidence: Psycho-Bayesian [?] Analysis and a Proposed Overhaul, 38 U.C.L.A. L. Rev. 637, 643 (1990) ("the prohibition against propensity evidence is deeply ingrained”); see also Old Chief v. United States, 519 U.S. 172, 182 (1997) ("There is, accordingly, no question that propensity would be an improper basis for conviction."); Greer v. United States, 245 U.S. 559 (1918) ("Courts that follow the common law tradition almost unanimously have come to disallow resort by the prosecution to any kind of evidence of a defendant's evil character to establish a probability of his guilt.").

${ }^{10}$ Note, supra note 5, at 436; see also Sherry F. Colb, "Whodunit" Versus "What Was Done:" When to Admit Character Evidence in Criminal Cases, 79 N.C. L. Rev. 939, 946 (2001). Albert Camus provided a poignant vignette of the propensity inference in his novel The Stranger. At the defendant's murder trial, the prosecution presented evidence of the defendant's lack of emotion at, and his conduct after, his mother's funeral, which occurred several months before the homicide. The prosecutor argued: "Gentleman of the jury, I would have you note that on the next day after his mother's funeral that man was visiting the swimming-pool, starting a liaison with a girl, and going to see a comic film. That is all I wish to say." When the defendant's lawyer objected, saying, "Is my client on trial for having buried his mother or for killing a man?" the prosecutor responded, "I accuse the prisoner of behaving at his mother's funeral in a way that showed he was already a criminal at heart." Albert Camus, The Stranger, 118, 121-22 (1988). 
character . . for the purpose of proving action in conformity therewith on a particular occasion."

Given the propensity prohibition, the practice of permitting the prosecution to impeach a defendant who testifies with evidence that he or she has previously been convicted of a crime is controversial. Commentators have recognized that the impeachment with prior convictions rule can easily be an "end run" around the anti-propensity rule, ${ }^{12}$ and have voiced the fear that "character evidence [will be] admitted under the guise of impeachment evidence even when it has very little probative value on the issue of credibility." 13

Thus, the debate over the current federal rule-Federal Rule of Evidence 609- has been accurately described as "sustained and strident."14 Some reformers fought for severe limitations, if not an outright ban, on the use of prior convictions for impeachment. ${ }^{15}$ Others argued that the use of prior convictions should be unrestricted in order to further the quest for

\footnotetext{
${ }^{11}$ FRE 404(a). The rule does have some exceptions. The most relevant one for the purposes of this article is FRE 404(b), which provides:

Evidence of other crimes, wrongs, or acts is not admissible to prove the character of a person in order to show action in conformity therewith. It may, however, be admissible for other purposes, such as proof of motive, opportunity, intent, preparation, plan, knowledge, identity, or absence of mistake or accident, provided that upon request by the accused, the prosecution in a criminal case shall provide reasonable notice in advance of trial or during trial, if the court excuses pretrial notice on good cause shown, of the general nature of any such evidence it intends to introduce at trial.
}

It is beyond the scope of this article, but in many of the wrongful conviction cases I reviewed for this study, the trial court permitted the prosecution to introduce other crimes or bad act evidence under equivalent state rules. See, e.g., People v. Jones, 620 N.E.2d 325 (Ill. 1993) (prosecution was permitted to introduce evidence of another rape allegedly committed by the subsequently exonerated defendant as evidence of common design); State v. Kordonouy, 823 P.2d 854 (Mont. 1991) (same); Johnson v. State, 388 S.E.2d 866 (Ga. App. 1989) (same). The admission of this type of evidence also contributes to wrongful convictions.

\footnotetext{
${ }^{12}$ Park, supra note 5 , at 812 .

${ }^{13}$ Note, supra note 5 , at 440 .
}

${ }^{14}$ Note, Impeachment by Prior Conviction: Adjusting to Federal Rule of Evidence 609, 64 Cornell. L. Rev. 416, 417 (1978); see also United States v. Smith, 551 F.2d 348, 360 (D.C. Cir. 1976) ("Rule 609 was one of the most hotly contested provisions in the Federal Rules of Evidence.").

${ }^{15}$ Note, supra note 14 , at 417 . 
truth. ${ }^{16}$ The version of the rule that ultimately carried the day was a compromise: crimes involving dishonesty or false statement may be used for impeachment; ${ }^{17}$ other convictions for crimes punishable by death or imprisonment in excess of one year may be used to impeach the defendant if the court determines that the "probative value of admitting the evidence outweighs its prejudicial effect to the accused." ${ }^{18}$ Most states have similar or even more "impeachment-friendly" rules. ${ }^{19}$ A few jurisdictions, however, prohibit or severely limit impeachment with prior convictions. ${ }^{20}$

In practice, the rules are honored in the breach. In most jurisdictions, the definition of crimes involving "dishonesty or false statement," which may be used for impeachment purposes without regard to any probative/

${ }^{16}$ Id. at 418 .

${ }^{17}$ FRE 609(a) (2) states that "evidence that any witness has been convicted of a crime shall be admitted if it involved dishonesty or false statement."

${ }^{18} \mathrm{FRE} 609$ (a) (1). The rule's balancing test is, in theory, more favorable to the defendant than the general exclusionary rule found in FRE 403. FRE 403 provides that relevant evidence "may be excluded if its probative value is substantially outweighed by the danger of unfair prejudice, confusion of the issues, or misleading the jury, or by considerations of undue delay, waste of time, or needless presentation of cumulative evidence." FRE 609, on the other hand, rather than requiring that the "probative value be substantially outweighed by the danger of unfair prejudice," mandates that impeachment should not be allowed unless "the probative value ... outweighs its prejudicial effect to the accused." Thus Rule 609 appears to establish a presumption against the admission of prior convictions not involving dishonesty or false statement for impeachment purposes. Gene R. Nichol, Jr., Prior Crime Impeachment of Criminal Defendants: A Constitutional Analysis of Rule 609, 82 W. Va. L. Rev. 391, 196 (1979-1980). As will be discussed later in this article, however, judges almost always conclude that the probative value of the prior conviction outweighs any prejudice to the accused.

${ }^{19}$ Alabama, Arizona, Arkansas, Delaware, Florida, Georgia, Illinois, Iowa, Kansas, Kentucky, Maine, Minnesota, Mississippi, Nebraska, Nevada, New Hampshire, New Mexico, North Dakota, Ohio, Oklahoma, South Carolina, South Dakota, Utah, Vermont, Washington, and Wyoming all have rules that are the same or substantially similar to FRE 609. California, Colorado, Idaho, Texas, and Virginia allow a defendant to be impeached with any felony conviction. North Carolina allows a defendant to be impeached with any felony and a number of misdemeanors. Louisiana, Maryland, Missouri, New Jersey, and Wisconsin allow a defendant to be impeached with any prior conviction. See the Appendix.

${ }^{20}$ Hawaii and Montana do not permit impeachment with prior convictions. State v. Santiago, 492 P.2d 657 (Ha. 1971); Mont. R. Evid. 609. West Virginia allows a defendant to be impeached with prior convictions only if the offense involves perjury or false statement and the court determines that the probative value of impeachment outweighs the prejudice to the accused. State v. McAboy, 236 S.E.2d 431 (W. Va. 1977); see also Nichol, supra note 18. 
prejudicial value balancing, has been construed very broadly. ${ }^{21}$ Additionally, despite the fact that when the prior conviction does not involve dishonesty or false statement, judges are supposed to permit impeachment only if the probative value outweighs the risk of unfairness to the accused, the balance is routinely struck in favor of impeachment. ${ }^{22}$ Even in cases where the prior conviction is for the same or a very similar offense, courts often allow the defendant to be impeached. For example, defendants accused of bank robbery have been impeached with evidence that they have been previously convicted of robbing banks. ${ }^{23}$ Defendants charged with murder have been impeached with prior convictions for murder ${ }^{24}$ defendants charged with narcotics offenses have been impeached with prior drug convictions; ${ }^{25}$ defendants charged with burglary have been impeached with prior burglary convictions $;{ }^{26}$ and defendants charged with robbery have been impeached with

\footnotetext{
${ }^{21}$ The legislative history of FRE 609 provides some guidance as to the meaning of dishonesty or false statement.

By the phrase "dishonesty and false statement" the Conference means crimes such as perjury or subornation of perjury, false statement, criminal fraud, embezzlement, or false pretense or any other offense in the nature of crimen falsi, the commission of which involves some element of deceit, untruthfulness, or falsification bearing on the accused's propensity to testify truthfully.
}

Joint Explanatory Statement of the Committee of Conference, H.R. Conf. Rep. No. 1597, 93d Cong., 2d Sess. 9, reprinted in 1974 U.S. Code Cong. \& Admin. News 7098, 7103.

All the crimes mentioned in the Conference Committee report have, not surprisingly, been deemed to involve dishonesty or false statement. Note, Character Evidence by any Other Name...." A Proposal to Limit Impeachment by Prior Conviction Under Rule 609, 58 Geo. Wash. L. Rev. 762, 778 (1989-1990). The courts are split as to whether crimes such as robbery, burglary, larceny, shoplifting, and drug offenses are "false statement" offenses. Id. Some courts look at the facts of the specific case to determine if it involved dishonesty or false statement. Id. at $778-79$.

${ }^{22}$ Id. at $779-81$.

${ }^{23}$ See, e.g., United States v. Brown, 794 F.2d 365, 366-67 (8th Cir. 1986).

${ }^{24}$ See, e.g., United States v. Fountain, 642 F.2d 1083, 1092 (7th Cir. 1981), cert. denied, 451 U.S. 993 (1981).

${ }^{25}$ See, e.g., State v. Spivey, 179 N.J. 229 (2004); United States v. Ortiz, 857 F.2d 900, 902 (2d Cir. 1988); People v. Caldwell, 122 Mich. App. 618 (1983).

${ }^{26}$ See, e.g., Triplett v. State, 881 So. 2d 303 (Ala. 2004); People v. Morris, 7 Ill. App. 3d 1055 (1972). 
priors for robbery and attempted robbery. ${ }^{27}$ When the prior conviction is for a different but nevertheless potentially very prejudicial crime, for example, rape or manslaughter, impeachment is also often permitted. ${ }^{28}$ Engaging in what would seem to be complete anti-logic, some courts have explicitly stated that they are permitting the prosecution to impeach the defendant given the "importance of the defendant's testimony and the centrality of his credibility to the defense." ${ }^{29}$

The convictions of the defendants who are so impeached are virtually never overturned on appeal. ${ }^{30}$ In addition to the natural reluctance appellate courts have toward reversing criminal convictions on discretionary evidentiary matters, ${ }^{31}$ the Supreme Court and most state courts have made it extraordinarily difficult to appeal issues regarding the trial court's decision to permit impeachment. In Lucev. United States, ${ }^{32}$ for example, the defendant was charged with federal drug offenses. The district court denied Luce's motion in limine and ruled that if Luce testified, the prosecution could impeach him with a prior state drug conviction. Luce elected not to testify. The Court held that "to raise and preserve for review the claim of improper impeachment with a prior conviction, a defendant must testify." ${ }^{33}$ In Ohler $v$. United States, ${ }^{34}$ the Court held that if the defendant with a prior record does

\footnotetext{
${ }^{27}$ See, e.g., United States v. Givens, 767 F.2d 574, 580 (9th Cir. 1985), cert. denied, 474 U.S. 953 (1985).

${ }^{28}$ See, e.g., United States v. Shaw, 701 F.3d 367, 385 (5th Cir. 1983) (defendant charged with murder was properly impeached with prior rape conviction); United States v. Jackson, 627 F.2d 1198, 1209 (D.C. Cir. 1980) (defendant charged with drug offenses was properly impeached with a prior manslaughter conviction). Given that, typically, only defendants can appeal evidentiary rulings, it is possible, though not likely, that trial judges bar impeachment more than this article suggests. My own experiences, and my discussions with prosecutors and criminal defense lawyers about this issue, do not, however, support such a conclusion.

${ }^{29}$ See, e.g., United States v. Browne, 829 F.2d 760, 763 (9th Cir. 1987).

${ }^{30}$ Note, supra note 21 , at 780 .

${ }^{31} \mathrm{~A}$ typical appellate decision involves a cursory determination that no abuse of discretion occurred. See, e.g., United States v. Hall, 588 F.2d 844 (8th Cir. 1978).

${ }^{32} 469$ U.S. 38 (1984).

${ }^{33} 469$ U.S. at 43.

${ }^{34} 529$ U.S. 753 (2000).
} 
testify, and if he or she preemptively elicits the fact of the conviction on direct examination in order to lessen its "sting," the defendant cannot challenge the trial court's ruling on appeal. ${ }^{35}$ Although these decisions are, technically, binding only in the federal system, they have been adopted by a number of state courts. ${ }^{36}$

Thus the defendant with a prior record, even one who is completely innocent of the charged offense, is between the proverbial rock and a hard place. $^{37}$ If he or she does testify, the defendant will frequently be impeached. ${ }^{38}$ When the jury hears of his or her prior record, it will generally draw one or more inferences: (1) the defendant is a bad person, therefore the defendant is lying, (2) the defendant is a bad person, he or she has done bad things in the past, thus it is more likely that the defendant committed the charged offense. Either inference-lack of credibility

${ }^{35} 529$ U.S. at 760 .

${ }^{36}$ See, e.g., State v. Allie, 710 P.2d 430 (Ariz. 1985) (holding that defendant must testify in order to raise improper impeachment issue on appeal); State v. Hunt, 475 S.E.2d 722 (N.C. 1996) (same).

${ }^{37}$ The choice can also be difficult for defendants with no record. The defendant may be nervous, lack intelligence, or his or her truthful direct testimony may incriminate the defendant. Griffin v. California, 380 U.S. 609, 613 (1965) ("It is not every one who can safely venture on the witness stand, though entirely innocent of the charge against him. Excessive timidity, nervousness when facing others and attempting to explain transactions of a suspicious character, and offenses charged against him, will often embarrass him to such a degree as to increase that than remove prejudice against him.”); see also Peter Aranella, Foreword: O.J. Lessons, 69 S. Cal. L. Rev. 1233, 1250 (1996). Under the federal sentencing guidelines, as well as under a number of state systems with similar features, the defendant who testifies and is convicted can expect to receive a longer sentence in the form of an obstruction of justice enhancement. Alexandra Natapoff, The Silencing of Criminal Defendants, 80 N.Y.U. L. Rev. 1449, 1461 (2005). Finally, if the defendant testifies, he or she may also open the door to the admission of evidence that was suppressed because it was obtained in violation of the Constitution. The Supreme Court has created a number of impeachment exceptions to the exclusionary rule. See, e.g., United States v. Havens, 446 U.S. 620 (1980) (defendant who testifies may be impeached with evidence obtained in an illegal search); Harris v. New York, 401 U.S. 422 (1971) (defendant who testifies may be impeached with a statement obtained in violation of Miranda ); Michigan v. Harvey, 494 U.S. 344 (1990) (defendant who testifies may be impeached with a statement obtained in violation of the Sixth Amendment right to counsel).

\footnotetext{
${ }^{38}$ In reviewing a draft of this article, George Fisher stated that prosecutors often, out of an excess of caution, decide not to use a prior conviction for impeachment purposes. Although that has not been my experience, it may be true and thus in the absence of more definitive empirical evidence, I make no broader statement regarding the likelihood of impeachment.
} 
or propensity-makes the jury more likely to convict. ${ }^{39} \mathrm{~A}$ third risk that arises from allowing the jury to consider prior conviction evidence is that doing so will lessen the state's burden to prove the defendant guilty beyond a reasonable doubt because the jury, even if it is not convinced the defendant committed the offense, will conclude that it is worse to acquit than it is to convict a bad person. ${ }^{40}$

If the defendant does not testify, then the jury is likely to draw the inference that he or she has something to hide or, more specifically, that the defendant is guilty. ${ }^{41}$ Even Supreme Court Justices are not above drawing this precise inference. Justice Scalia stated in Mitchell v. United States: "If I ask my son whether he saw a movie that I had forbidden him to watch, and he remains silent, the import of his silence is clear." ${ }^{42}$ This inference also makes

\footnotetext{
${ }^{39}$ Harry Kalven \& Hans Zeisel, The American Jury (1966) (admission of a defendant's prior convictions increased the rate of conviction for the charged offense by 27 percent). In fact, however, the inferences are virtually the same. The theory of impeachment must logically run as follows: (1) the defendant in fact previously committed a crime; (2) a person who has committed this crime has a character deficit that makes it more likely that he or she will lie; (3) the defendant is acting in conformity with the defendant's character. Hornstein, supra note 7, at 13-14. This is evident from the classic statement providing the theoretical underpinning of prior crime impeachment offered by Justice Holmes:

[W] hen it is proved that a witness has been convicted of a crime, the only ground for disbelieving him which such proof affords is the general readiness to do evil which the conviction may be supposed to show. It is from that general disposition alone that the jury is asked to infer a readiness to lie in the particular case, and thence that he has lied in fact. The evidence has no tendency to prove that he was mistaken, but only that he has perjured himself, and it reaches the conclusion solely through the general proposition that he is of bad character and unworthy of credit.
}

Gertz v. Fitchburg R.R., 137 Mass. 77, 78 (1884).

${ }^{40}$ Nichol, supra note 18 , at 408 .

${ }^{41}$ James Beaver \& Steven Marques, A Proposal to Modify the Rule on Criminal Conviction Impeachment, 58 Temp. L.Q. 585, 587 (1985) ("Jurors expect innocent defendants to respond to false criminal accusations. From silence jurors draw an inference of guilt. The defendant who appears to withhold reluctant information is likely to be viewed as guilty."); see also Wigmore, Evidence $\$ 2272$, p. 426 (McNaughton rev. 1961) ("What inference does a plea of privilege support? The layman's natural first suggestion would probably be that the resort to privilege in each instance is a clear confession of a crime."); Lewis Mayers, Shall We Amend the Fifth Amendment 21 (1959).

${ }^{42} 526$ U.S. 314, 333 (Scalia, J., dissenting). 
it more likely the jury will convict. ${ }^{43}$ The jury is likely to disregard an instruction that this inference is not permissible. ${ }^{44}$

\section{The EMPirical Evidence}

I compiled the data relied on in this article as follows. First, I reviewed the case summaries of the 172 exonerated individuals through the end of 2006 maintained by the Innocence Project. ${ }^{45}$ If the defendant was not exonerated through DNA evidence, I excluded that case for the purpose of this study. ${ }^{46}$ This left a pool of 152 cases. To determine whether the defendants in these cases testified, I reviewed all available judicial opinions, all available case summaries maintained by the Innocence Project and its affiliated organizations, the trial transcripts in approximately 30 cases, and I attempted to contact either the exonerated individual or his or her attorney. Using these

\footnotetext{
${ }^{43}$ Nichol, supra note 18 , at 401 .

${ }^{44} \mathrm{~A}$ defendant is entitled to a "no adverse inference" instruction that admonishes the jury that the defendant's failure to testify may not be held against him or her. Carter v. Kentucky, 450 U.S. 288 (1981). If the defendant testifies and is impeached with prior convictions, the jury will be charged that the prior conviction may be considered by the jury only in evaluating the defendant's credibility and may not be considered as evidence of guilt. See, e.g., Connecticut Selected Jury Instructions, Criminal § 2.23. However, judges and scholars have long recognized that these instructions are a "placebo" and a "judicial lie." United States v. Grunewald, 233 F.2d 556. 574 (2d Cir. 1956). Judge Hand addressed this topic on a number of occasions. In his view, the limiting instruction was a "recommendation to the jury of a mental gymnastic which is beyond, not only their powers, but anybody else's." Nash v. United States, 54 F.2d. 1006, 1007 (2d Cir. 1932). He also referred to limiting instructions of this type as "placebo" and a "judicial lie." Justice Stone made a similar observation. See also Raffel v. United States, 271 U.S. 494, 499 (1926) ("every person accused of crime is under some pressure to testify, lest the jury, despite carefully framed instructions, draw an unfavorable inference from his silence"). Jury studies have confirmed that jurors exposed to a defendant's criminal past for the purpose of impeaching his or her credibility use the information as an indication that the defendant was "more likely than not guilty of the crime." Comment, Other Crimes Evidence at Trial: Of Balancing and Other Matters, 70 Yale L.J. 763, 777 (1961); see also Roselle Wissler \& Michael Saks, On the Inefficacy of Limiting Instructions: When Jurors Use Prior Conviction Evidence to Decide on Guilt, 9 J. Law \& Hum. Behav. 37 (1985) (mock jurors found defendants with a prior record guilty at higher rates in cases otherwise involving the same evidence despite being provided with a limiting instruction); Valerie Hans \& Anthony Doob, Section 12 of the Canada Evidence Act and the Deliberations of Simulated Juries, 18 Crim. L.Q. 235 (1976) (same).
}

\footnotetext{
${ }^{45}$ See 〈http:/ / www.innocenceproject.org. $\rangle$

${ }^{46}$ I did so in order to reduce "quibbling" about whether a particular individual was truly innocent.
} 
sources, I was able to determine whether 119 of the 152 wrongfully convicted defendants did or did not testify. I also ascertained, in 56 cases, whether the defendant had a prior criminal record.

To compare the pattern of defendant testimony and prior criminal record in the innocence cases with the pattern in a representative group of general criminal cases, I relied on data collected by the National Center for State Courts (NCSC) as part of a project funded by the National Institute of Justice. These data reveal that in 2000-2001 in four major metropolitan areas (the Bronx, the District of Columbia, Los Angeles, and Phoenix), criminal defendants testified in 163 of 330 (49.4 percent) of cases. ${ }^{47}$ The available evidence thus indicates that approximately one half of all criminal defendants testify at their trials. Defendants without criminal records, not surprisingly, testify more frequently than do defendants with prior records. Sixtyone percent (73 of 119) of the wrongfully convicted defendants testified at their trials. ${ }^{48}$ Although this is slightly higher than the percentage of criminal defendants generally who take the witness stand, it is not substantially

\footnotetext{
${ }^{47}$ The NCSC data are described in [Theodore Eisenberg \& Valerie P. Hans, Taking a Stand on Taking the Stand: The Effect of a Prior Criminal Record on the Decision to Testify and on Trial Outcomes (Cornell Legal Studies Research Paper No. 07-012 2007), available at 〈http:// ssrn.com/abstract=998529,tbl/ $>$ ]. The NCSC rate of defendant testimony is consistent with an older study conducted in Philadelphia that indicated that 50 percent of felony defendants testified. Stephen Schulhofer, Some Kind Words for the Privilege Against Self-Incrimination, 26 Val. U. L. Rev. 311, 329-30 (1991). A study of misdemeanor cases in Philadelphia indicated that defendants testify in 43 percent of all cases. Stephen Schulhofer, No Job Too Small: Justice Without Bargaining in Lower Criminal Courts, Am. B. Found. Res. J. 519 (1985). Other, more limited studies place the defendant testifying rate slightly higher. Norman Poythress, Richard Bonnie, Steven Hoge, John Monahan \& Lois Oberlander, Client Abilities to Assist Counsel and Make Decisions in Criminal Cases: Findings from Three Studies, 18 Law \& Hum. Behav. 437, 448 (2005) (finding that the defendant testified in 10 of 14 cases in the study). The number of defendants who testify appears to have fallen since the 1950s. Kalven and Zeisel found that 91 percent of the defendants without records testified at trial, and 74 percent of defendants with a prior record testified in their own defense. Supra note 37 , at 136 . This is likely due to the availability, upon request, of a no adverse inference instruction. See note 44 supra.

${ }^{48}$ At present, I have data on approximately 80 percent of the DNA exoneration cases. More than half the "exonerees" had prior convictions. This is not surprising given that the police often solve crimes using the propensity inference and rounding up the "usual suspects." In a rape case, for example, it is not uncommon for the police to show the victim a photographic lineup comprised of individuals who have previously been convicted of sexual offenses. The empirical evidence suggests that when confronted with such a lineup, the victim will approach the task like a multiple-choice test and pick the person who looks most like the perpetrator. Gary L. Wells \& Eric P. Seelau, Eyewitness Identification: Psychological Research and Legal Policy in Lineups, 1 Psychol., Pub. Pol'y \& L. 765, 772 (1995).
} 
higher. Thus, the data indicate that a large number of innocent defendants do not testify.

Defendants without criminal records, not surprisingly, testify more frequently than do defendants with prior records. ${ }^{49}$ Of the 56 innocent defendants who did testify for which information is available, only 24 (43 percent) had prior criminal records that the prosecution could have put before the jury for the purpose of testing the defendant's credibility. ${ }^{50} \mathrm{O}$ the innocent wrongfully convicted defendants who failed to testify for which information was available, 32 of 35 (91 percent) had prior convictions that potentially could have been used for impeachment purposes had they exercised their constitutional right to tell their story. ${ }^{51}$

The relevant state rules of evidence do appear to be the primary determining factor in whether the defendant takes the stand. In every single case in which a defendant with a prior record testified, the trial court permitted the prosecution to impeach the defendant with his or her prior convictions. Although some of the prior convictions involved "false statement" crimes that were automatically admissible impeachment material, ${ }^{52}$ in most cases, the trial court made the determination that the probative value

\footnotetext{
${ }^{49}$ One recent study finds that 62 percent of defendants without criminal records testify and 45 percent with criminal records testify. Theodore Eisenberg \& Valerie P. Hans, Taking a Stand on Taking the Stand: The Effect of a Prior Criminal Record on the Decision to Testify and on Trial Outcomes (August 8, 2007), Cornell Legal Studies Research Paper No. 07-012, available at 〈http://ssrn.com/abstract=998529.. . Some studies indicate that in cases where the defendant with a prior record testified, the trial court permitted the prosecution to impeach the defendant in 70 percent of the cases. Natapoff, supra note 37, at 1461.

${ }^{50}$ Although 33 of the 56 defendants where the determination can presently be made had prior records, under the relevant state rule of evidence, only 24 defendants had prior crimes that could have been used for the purpose of impeachment. Eisenberg and Hans found in their study that the jury learned of the defendant's prior record in approximately one-half of the cases in which the defendant testified. Eisenberg \& Hans, supra note 50, at 3. However, their data did not permit a determination of whether the prior conviction could have been used for impeachment purposes.
}

\footnotetext{
${ }^{51}$ Thirty-two of 35 defendants who did not testify had prior convictions that, under the evidence rules of the relevant state, could potentially have been used for impeachment purposes. In three cases, the defendant had no prior record, and in another 11 cases I have not yet been able to make the pertinent determination.

${ }^{52}$ For example, Richard Danzinger, who spent nearly a decade in a Texas penitentiary for a crime he did not commit, had previously been convicted of forgery. There were no cases in which the defendant had previously been convicted of perjury.
} 
Table 1: Rate of Testimony at Trial by Defendants with Prior Criminal Records

\begin{tabular}{lcc}
\hline & $\begin{array}{c}\text { Defendant } \\
\text { Testified }\end{array}$ & $\begin{array}{c}\text { Defendant Did } \\
\text { Not Testify }\end{array}$ \\
\hline Innocence data (this study) & 3 & 32 \\
NCSC data & 114 & 137 \\
\hline
\end{tabular}

of the evidence was not outweighed by prejudice to the accused $;{ }^{53}$ this was true even when the defendant's prior conviction was for the same or a very similar offense. ${ }^{54}$ In almost all instances in which a defendant with a prior record did not testify, counsel for the wrongfully convicted defendant indicated that avoiding impeachment was the principal reason the defendant did not take the stand. ${ }^{55}$ On the other hand, in the few jurisdictions where impeachment with prior convictions is not permitted, for example, West Virginia and Montana, all the wrongfully convicted defendants testified. ${ }^{56}$ Each of these defendants had prior convictions that, in other jurisdictions, could have been used to impeach them. ${ }^{57}$

Table 1 compares the rate of testimony by defendants with criminal records in the innocence data set with the rate of testimony by defendants with criminal records in the NCSC data. The table shows that the 91 percent nontestimony rate in the innocence data far exceeds the 55 percent (137 of 251) rate at which defendants did not testify in the sample of general

\footnotetext{
${ }^{53}$ For example, Kirk Bloodsworth, who was erroneously convicted of a Maryland murder, was impeached with a prior drug offense. Herman Atkins, wrongfully convicted of a California robbery and rape, was impeached with a prior conviction for assault on a police officer. Habib Wahir Abdal was convicted of committing a rape in New York. He was impeached with a prior conviction for manslaughter.

${ }^{54}$ For example, Ronald Cotton was convicted of burglary and rape in North Carolina. After denying his guilt, he was impeached with prior convictions for assault with intent to commit rape and breaking and entering. Kerry Kotler, erroneously convicted of rape and robbery in New York, was impeached with a prior conviction for statutory rape. Frank Smith, wrongfully convicted of a Florida murder, was impeached with a prior manslaughter conviction.

${ }^{55}$ Either the exonerated individual or counsel were interviewed in 24 of the 35 cases.

${ }^{56}$ Seven individuals have been exonerated by DNA evidence in West Virginia and Montana.

${ }^{57}$ Interview with George Castelle, counsel for West Virginia Innocence Project (on file with author).
} 
criminal cases. The difference in rates is highly statistically significant $(p<0.0001)$.

The comparison is, of course, subject to two important assumptions. First, it assumes that the innocence cases for which information is available reasonably represent the universe of innocence cases. There is no reason to believe that is not the case but it is an assumption underlying the comparison. Second, it assumes that the overwhelming majority of defendants in the general criminal NCSC sample are guilty (at least of something) and that the NCSC data are a reasonable proxy for the larger universe of criminal cases. Again, these assumptions are in accord with common sense and other known facts about the criminal justice system.

Subject to these limitations, the currently available data, therefore, suggest that many demonstrably innocent defendants did not testify at trial because, had they done so, they would have been impeached with their prior convictions. ${ }^{58}$ This is evident both from the fact that more than 90 percent of the nontestifying innocent defendants, as opposed to only 40 percent of the testifying defendants, had prior convictions involving potentially impeachable offenses, as well as from the fact that all defendants with prior records in states where impeachment with prior convictions was not permitted chose to take the stand. The data further suggest a possible association between failure to testify in capital cases and innocence.

The data from the wrongful conviction cases also reveal the shortcomings of the current regulatory system, which gives trial courts discretion in most cases to allow or preclude impeachment. In every single instance where an innocent defendant with a prior conviction for an impeachable offense elected to testify, the court permitted the prosecution to impeach the defendant.

So, where does this leave us?

\section{Proposals for Reform}

I propose the following modification to rules of evidence regulating impeachment with prior convictions. The prosecution should not be

\footnotetext{
${ }^{58}$ It is difficult to say that this decision was wrong. Eisenberg and Hans found a statistically significant association between the jury learning of the defendant's prior record and the likelihood of conviction in cases with weak evidence. Eisenberg \& Hans, supra note 50, at 3.
} 
permitted to impeach a criminal defendant's testimony with evidence that he or she has previously been convicted of a crime unless: (1) the defendant has been previously convicted of perjury and the court determines that the probative value of permitting impeachment outweighs the prejudice to the accused; or (2) the defendant "opens the door" by offering evidence of his or her character for truthfulness. ${ }^{59}$

There are at least three reasons for making these needed changes to the current legal regime. First, the data I discussed in the previous section of this article confirm that threatening a defendant with the introduction of his or her prior record contributes to wrongful convictions either directly-in cases where the defendant is impeached with the prior record and the jury draws the propensity inference-or indirectly—by keeping the defendant off the stand. ${ }^{60}$ The current rules strongly discourage defendants, even innocent

\footnotetext{
${ }^{59}$ Some commentators who have proposed reforming the current impeachment regime have argued that impeachment should be permitted if the defendant has a prior conviction involving perjury or false statement. In other words, that FRE 609(a), or it state equivalents, should be retained. My proposal eliminates the "false statement" requirement entirely. I do so for several reasons. First, given the expansive definition given of crimes involving false statement, it encompasses too broad an array of offenses. Second, I am not convinced that the probative value of the so-called lying crimes is substantially higher than that of other offenses. See Richard Spector, Impeaching the Defendant by His Prior Conviction and the Proposed Rules of Evidence: A Half Step Forward and Three Steps Backward, 1 Loy. U. Chi. L.J. 247, 252 (1970); Note, To Take the Stand or Not to Take the Stand: The Dilemma of the Defendant with a Criminal Record, 4 Colum. J.L. \& Soc. Probs. 215, 219 (1968). More controversial is my proposal that even convictions for perjury can be used for impeachment only if the court determines that the probative value of permitting impeachment is outweighed by the prejudice to the accused. Nevertheless, I think this is the best course. First, a perjury conviction, in most instances, generally only proves that the defendant was a particularly inept or stupid liar in a prior proceeding. If that is the best the defendant can do, then there is little risk that the jury will be "hoodwinked" by his or her trial testimony. Second, making a perjury conviction per se admissible for impeachment purposes effectively eliminates any possibility that the defendant can testify in his or her own defense. Although the probative/prejudice calculus will, as we have seen, almost certainly be struck in the prosecution's favor in the majority of cases, that decision should be left to the trial court. It may turn out that the exception swallows the rule; if so, then even the use of perjury convictions should be precluded. It may also be the case that if my proposal were adopted, prosecutors would bring more perjury cases against defendants who testify and are subsequently convicted. I think that is unlikely, but even if that were the result, I would still advocate for this proposal, given the strong evidence that many innocent defendants are discouraged from testifying under the present legal regime.
}

${ }^{60}$ Note, supra note 5 , at 442 . 
defendants, from taking the witness stand and telling their stories. That in and of itself is a reason to modify the impeachment rules. ${ }^{61}$

Second, there is no reason to believe that precluding impeachment will lead jurors to place too much weight on a defendant's testimony. Proponents of impeachment will inevitably push back on fairness grounds, arguing that such a limitation allows a defendant a windfall because the jury will assume-in the absence of evidence to the contrary-that he or she is person of good character. However, that assumption is speculative. I am aware of no empirical information indicating it to be true. Indeed, the available empirical evidence is that jurors do not associate prior criminal record with a defendant's believability. ${ }^{62}$ More importantly, common sense tells us that jurors will inevitably view a defendant's testimony skeptically. A defendant charged with a serious crime facing years of incarceration, or even the death penalty, is highly motivated to lie. ${ }^{63}$ That fact is not lost on jurors, and even if it was, jurors are specifically instructed to consider a witness's interest in the outcome. ${ }^{64}$ This trial reality already substantially diminishes the

\footnotetext{
${ }^{61}$ It is not as if such a regime is unthinkable. Most continental systems bar the use of prior conviction to impeach a defendant. Gordon Van Kessell, Adversary Excesses in American Criminal Law, 67 Notre Dame L. Rev. 403, 515 (1992) ("Continental defendants nearly always give their side of the case at trial because a refusal to do so has clear negative implications and choosing to speak does not open the accused to damaging prior conviction impeachment.").
}

${ }^{62}$ Eisenberg \& Hans, supra note 50, at 31.

${ }^{63}$ Hornstein, supra note 7 , at 15 ("with respect to the credibility question there is already substantial doubt about the defendant's veracity arising from his or her interest in the outcome"); Friedman, supra note 9, at 659 .

${ }^{64} \mathrm{~A}$ typical instruction is set forth below.

Now, in saying that you must consider all of the evidence, I do not mean that you must accept all of the evidence as true or accurate. You should decide whether you believe what each witness had to say, and how important that testimony was. In making that decision you may believe or disbelieve any witness, in whole or in part. Also, the number of witnesses testifying concerning any particular dispute is not controlling.

In deciding whether you believe or do not believe any witness I suggest that you ask yourself a few questions: Did the witness impress you as one who was telling the truth? Did the witness have any particular reason not to tell the truth? Did the witness have a personal interest in the outcome of the case? Did the witness seem to have a good memory? Did the witness have the opportunity and ability to observe accurately the things he or she testified about? Did the witness appear to understand the questions clearly and answer them directly? Did the witness's testimony differ from other testimony or other evidence? 
defendant's credibility. ${ }^{65}$ If the defendant does decide to make his or her good character part of the defense presentation, the prosecution is then free to counter that evidence with evidence of prior misdeeds. ${ }^{66}$

Third, except where the defendant has been previously convicted of perjury, there is no reason to believe that individuals with a prior record are more likely to lie under oath than defendants without prior records. Most individuals charged with a serious crime would lie on the witness stand depending on their assessment of two variables: (1) the importance of having the untruthful testimony believed; and (2) their level of confidence that the false testimony will achieve that end without undue risk. ${ }^{67}$ The current rules must assume that a defendant without a prior record is more likely to tell the truth (even though he or she may be guilty), and that a defendant with a prior record is more likely to lie (even though the defendant may be innocent).$^{68}$ But that assumption is faulty; recidivists and firsttime offenders have similar incentives to lie if they are facing similar punishment. ${ }^{69}$ Allowing the prosecution to introduce evidence of the defendant's prior criminal convictions creates too great a risk that the jury will convict either by placing too much weight on the defendant's prior record in

Pattern Jury Instructions (Criminal) \& Resolution Filed by the Judicial Counsel of the 11th Circuit (Jan. 2, 2003), available at 〈http://www.cal1.uscourts.gov/documents/jury/ crimjury.pdf $\rangle$ (emphasis in original).

${ }^{65}$ Friedman, supra note 9 , at 659.

${ }^{66}$ Such a situation would arise, for example, when the defendant testifies and maintains, for example, that he or she has never been in trouble, has lived a blameless life, and so forth.

${ }^{67}$ H. Richard Uviller, Credence, Character, and the Rules of Evidence: Seeing Through the Liar's Tale, 42 Duke L.J. 776, 813 (1993). For example, innocent defendants will generally tell the truth insofar as doing so promotes acquittal. However, they may lie or omit facts that increase suspicion. Guilty defendants who testify will lie about anything that might improve their chances of acquittal and about which they believe they can lie persuasively. Id. This is not to say that some people, in some situations, may lie just for the sake of lying. See J.D. Salinger, Catcher in the Rye (1951). However, most people tell most of the truth most of the time.

${ }^{68}$ The social science literature indicates, consistent with common sense, that lying is a complex and subtle process. Uviller, supra note 67, at 813; see also William Shakespeare, The Merchant of Venice act 1, sc. 3, line 101, in The Complete Works (Stanley Wells \& Gary Taylor, eds., 1988) ("O, what a godly outside falsehood hath").

${ }^{69}$ Richard Posner, An Economic Approach to the Law of Evidence, 51 Stan. L. Rev. 1477, 1527 (1999). 
assessing credibility or, more directly, by drawing the inference that the defendant is a bad person who deserves to be punished. ${ }^{70}$ Either possibility lessens the prosecution's burden of proof and creates the risk of not only unfair, but, as I have demonstrated, erroneous convictions. ${ }^{71}$ Current rules of impeachment also unduly burden a defendant's constitutional right to testify, forcing him or her to pay too high a price for exercising the right to tell the defendant's story. ${ }^{72}$

Critics of curtailing impeachment with prior convictions will certainly argue that relaxation of the current rules will encourage more guilty defendants to testify falsely. That is certainly possible. On the other hand, the defendant is still subject to cross-examination and his or her testimony may be impeached through other means. ${ }^{73}$ Generally, true stories will be more

\footnotetext{
${ }^{70}$ Many convictions used for impeachment purposes were obtained as a result of guilty pleas. There are many reasons to question whether many defendants are in fact guilty of the underlying offense. For example, due to jail overcrowding and large criminal dockets in major metropolitan areas, many defendants plead guilty in order to obtain their immediate release or to get to a less restrictive custodial environment rather than spending a substantial amount of time in a local jail awaiting a trial date. See, e.g., Carl McGowan, Impeachment of Criminal Defendants by Prior Convictions, 1970 Law \& Soc. Order 1, 12. Then circuit judge, and later Chief Justice, Burger noted this reality in Gordon v. United States, 383 F.2d 936, 940 n.8 (D.C. Cir. 1967) ("The relevance of prior convictions to credibility may well be different between a case where the conviction of the accused was by admission of guilt by a plea and on the other hand a case where the accused affirmatively contested the charge.").

${ }^{71}$ Clarrence Darrow once said that "[o]ne conviction is generally all the evidence that is needed to justify a second one." C. Darrow, The Story of My Life 193 (1966).

${ }^{72}$ In other contexts, the Supreme Court has invalidated practices that unfairly burdened the assertion of a constitutional right. See, e.g., Griffin v. California, 380 U.S. 609, 614 (1965) (holding that neither the court nor the prosecution may comment on the defendant's failure to testify because such comments are a "penalty imposed ... for exercising a constitutional privilege"). The Court has also recognized that a defendant has the right to "present the defendant's version of the facts ... to the jury so it may decide where the truth lies." Washington v. Texas, 388 U.S. 14, 19 (1967). For a more detailed explanation of this constitutional argument, see Nichol, supra note 18, at 408-10.
}

${ }^{73}$ Some readers will ask, "What about Federal Rule of Evidence 608 ?" which allows the credibility
of a witness to be impeached with opinion and reputation evidence of his or her character for
untruthfulness. Rule 608 has several other noteworthy features: (1) it allows for evidence of a
witness's truthful character only after the witness's character for truthfulness has been attacked
(FRE 608 (a)); (2) specific instances of conduct of a witness, with the exception of evidence of
a prior conviction as provided in Rule 609 , cannot be proven by extrinsic evidence (FRE
608 (b)), but may, in the court's discretion, be inquired into on cross-examination of the witness
concerning the witness's character for truthfulness or untruthfulness. Id. The short answer is 
convincing than false ones. ${ }^{74}$ Although there is undoubtedly some risk of mistaken acquittal, on balance, that risk is outweighed by the greater risk of wrongful conviction if the current rules are left intact. Our criminal justice system and our society have committed to the principle that "it is far worse to convict an innocent man than to let a guilty man go free." 75 That commitment is hollow indeed if the current evidentiary regime is not altered. ${ }^{76}$

that Rule 608 should not be permitted to serve as an "end run" around the modifications to the impeachment rule discussed previously. For example, the prosecution should not be permitted to call police officers who have been involved in cases resulting in the defendant's prior convictions to testify to the defendant's poor character for truthfulness. It would be obvious to virtually all jurors that their opinion was based on prior criminal conduct and, for the reasons set forth previously, the prior convictions shed little light on a person's truthfulness. However, if the witness's opinion regarding the defendant's character for untruthfulness was based on other relevant and probative information, for example, a history pattern of lying about important matters, then the testimony may, subject to Rule 403's limitation on unduly prejudicial evidence, be admissible.

${ }^{74}$ Another possible penalty for false testimony is that the defendant's sentence, if he or she is convicted, may be enhanced if the judge concludes that the defendant has committed perjury in his or her defense. Monroe Freedman, Getting Honest About Client Perjury, 21 Geo. J. Legal Ethics 133, 160 (2008).

${ }^{75}$ In re Winship, 397 U.S. 358, 372 (1970) (Harlan, J., concurring); see also Schlup v. Delo, 513 U.S. 298, 325 (1995) (same); Arizona v. Youngblood, 488 U.S. 51, 73 (1988) (same); Taylor v. Illinois, 484 U.S. 400, 437 (1988) (same); Johnson v. Louisiana, 406 U.S. 380, 393 (1972 (same). Blackstone noted in his commentaries that is it better "that ten guilty persons escape than that one innocent person suffer." 4 William Blackstone, Commentaries 358. Starkie opined that it is "the maxim of the law ... that it is better that ninety-nine offenders should escape, than that one innocent person should be condemned." Thomas Starkie, Evidence 756 (1824).

${ }^{76}$ I also think an argument can be made that in cases where the defendant decides not to testify for whatever reason, for example, lack of intelligence or poor demeanor, a much stronger limiting instruction should be given. Although it is certainly possible that even the best of limiting instructions will not prevent jurors from considering a defendant's silence as evidence of guilt, efforts should be made. Given the findings set forth above, limiting instructions should specifically inform the jury that innocent defendants sometimes do not testify and that recent evidence has established that innocent defendants who did not testify were erroneously convicted. An example of a potentially more effective jury instruction is set out below.

Ladies and gentleman of the jury, I have previously discussed with you the presumption of innocence. As I said, a defendant is never required to prove his innocence. In fact, a defendant is not required, or even expected, to offer any evidence at all. Rather the burden of proof remains on the prosecution at all times to prove that the defendant is guilty beyond a reasonable doubt.

In this case the defendant did not testify. You should not consider his failure to testify in any way whatsoever during your deliberations. There are many reasons that a defendant might not testify on his own behalf that have absolutely nothing to do with whether he is 


\section{Conclusion}

In this article, I have presented empirical evidence suggesting that the current rules of evidence, which permit criminal defendants to be impeached with a wide range of prior convictions, contribute to wrongful convictions. Based on this evidence, I have argued for a change in the rules of evidence, a change that would permit criminal defendants to decide whether to testify on their own behalf without having to calculate the risk that, if they do exercise the constitutional right to testify, the jury will learn of their prior convictions. If impeachment with prior convictions is not permitted, except under very limited circumstances, it will not be "the end of the world as we know it."77 More (but not all) defendants will decide to testify on their own behalf, and thus more juries will have more information about the criminal offense itself to consider in determining whether the defendant is guilty of the offense. That is a good thing. Those defendants who do not testify should be provided with more protection because, as this study reveals, sometimes even the demonstrably innocent do not take the witness stand, look the jury in the eye, and proclaim their innocence. If it is truly the case that it is worse for an innocent person to be convicted than it is for a guilty person to go free, the rules of evidence must be changed. If they are not, then there are two classes of justice, one for "us" and one for "them." ${ }^{\text {"T }}$ The "them," those who have been previously convicted, receive a second-class, watered-down right to a fair trial in which the propensity inference is king.

guilty of the offenses he is accused of committing. While you may be tempted to think that only guilty defendants do not take the witness stand, I can assure you that it not true. Defendants who are innocent also frequently do not testify. Recent studies have conclusively established that a number of individuals who were wrongfully convicted of crimes they did not commit, many of whom spent years in prison before their innocence was discovered, did not testify at their trials. Thus a defendant's failure to testify has absolutely no bearing on whether he committed the charged offense and it should not be considered by you in any way whatsoever. If you do, there is a possibility that you will convict an innocent man.

${ }^{77}$ REM, It's the End of the World as We Know It (and I Feel Fine), on Document (Capitol Records 1987).

${ }^{78}$ The silencing of criminal defendants undermines the integrity of the criminal justice system in other important but less quantifiable ways. The majority of criminal defendants are poor, uneducated, and people of color. As such, their voices are seldom heard and, if heard, even more rarely listened to. Testifying at trial is the "quintessential embodiment of the defendant's right to speak for himself." Natapaff, supra note 37, at 1459. If we are to expect, or at least hope, that the broader community have respect for the criminal justice system, especially those who are more likely to feel its brunt, then its rules should encourage defendants to testify. 


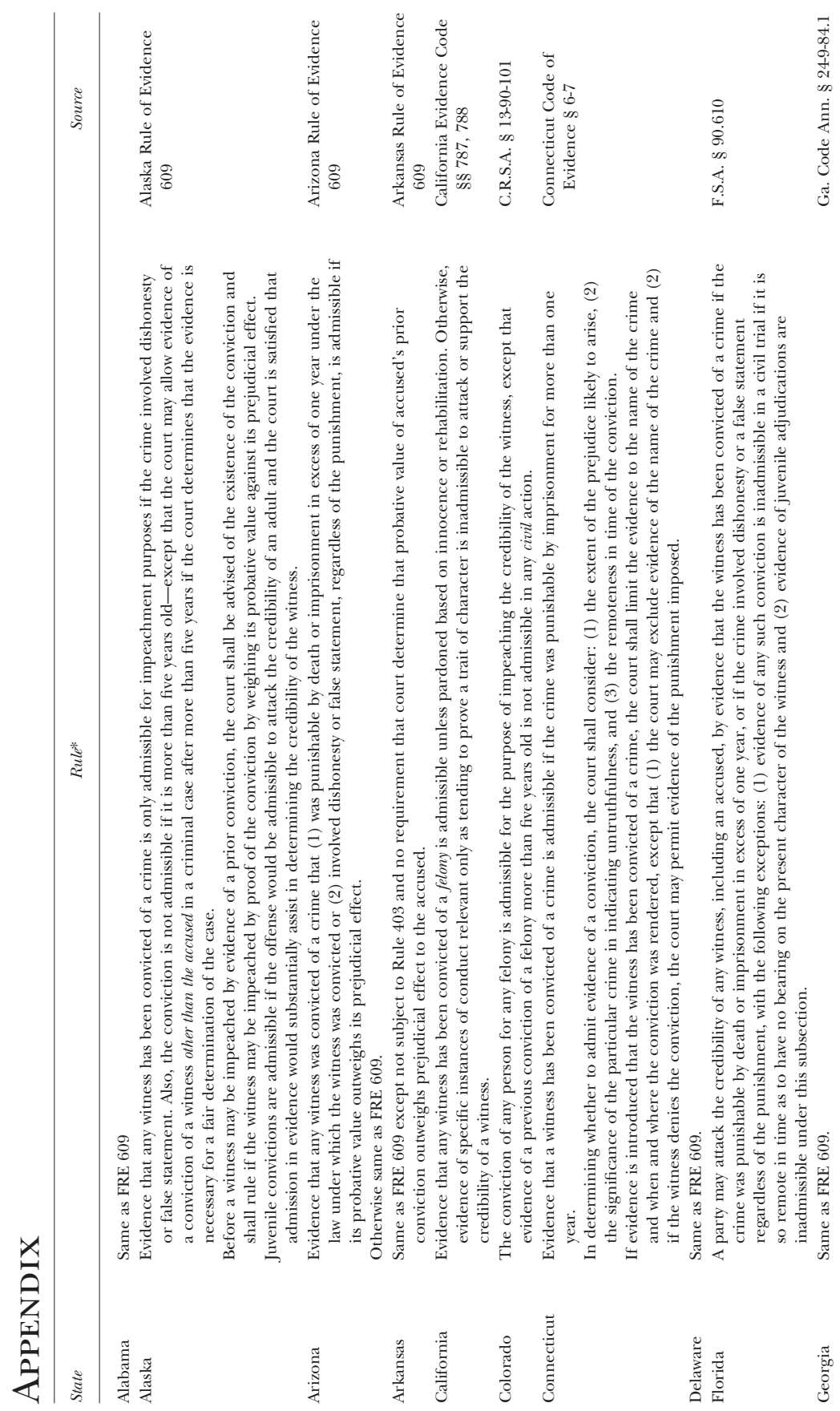




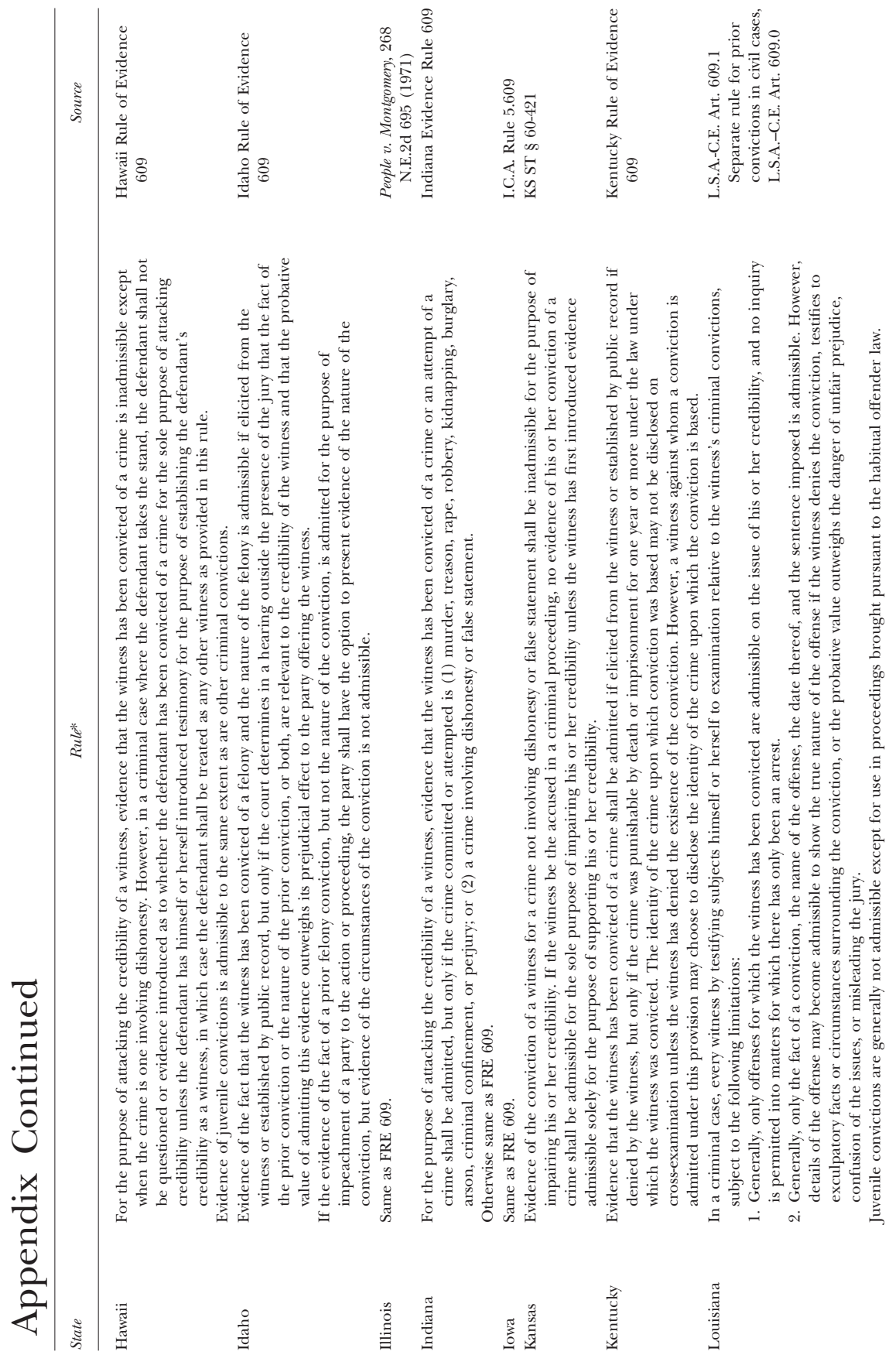



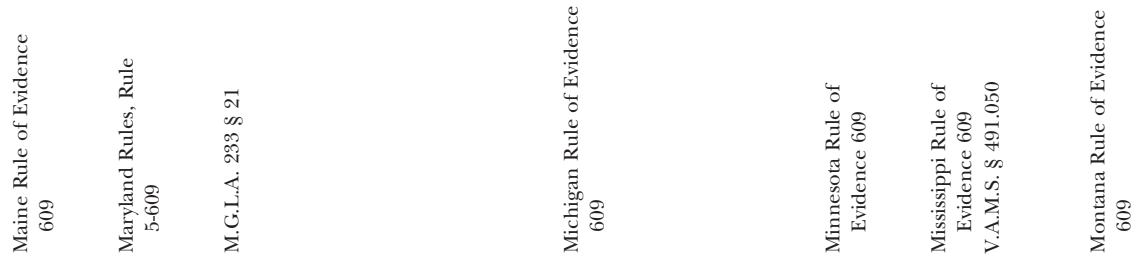

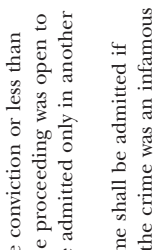

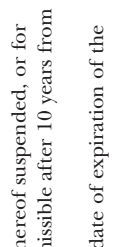

5.

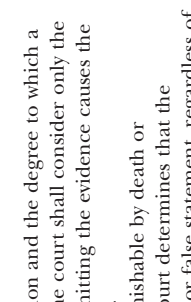

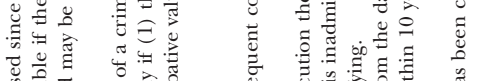

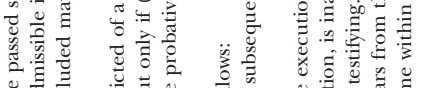

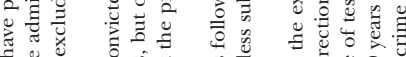

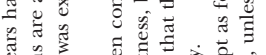

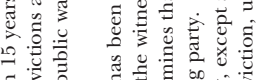

元

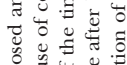

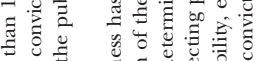

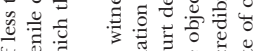

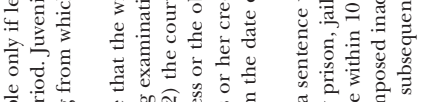

䒠

के

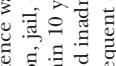

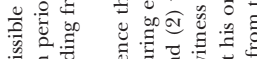

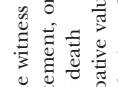

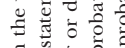

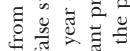

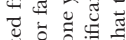

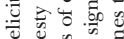

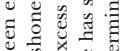

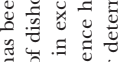

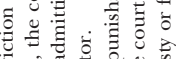

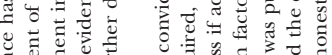

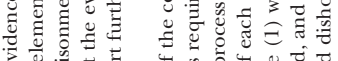

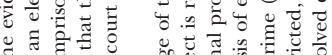

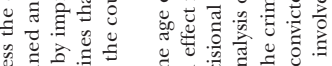

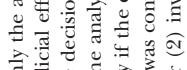

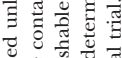

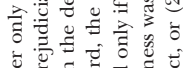

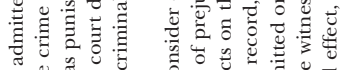

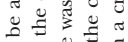

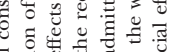

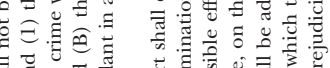

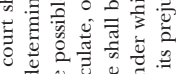

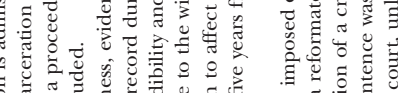

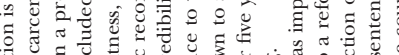

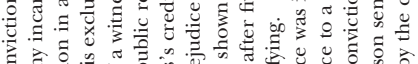

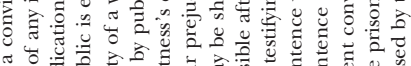

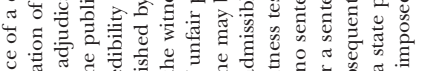

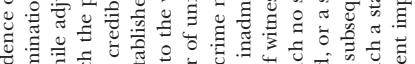

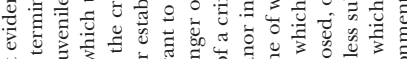

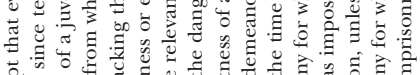

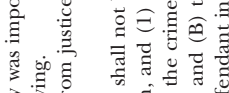

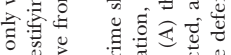

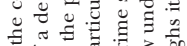

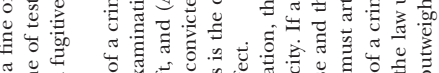

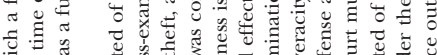

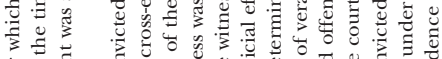

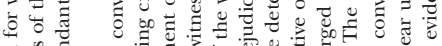

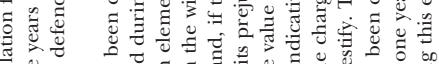

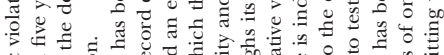

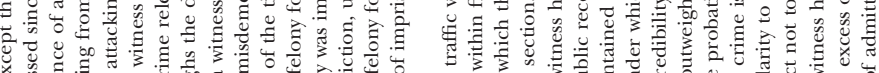

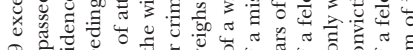

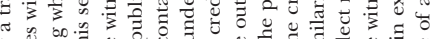

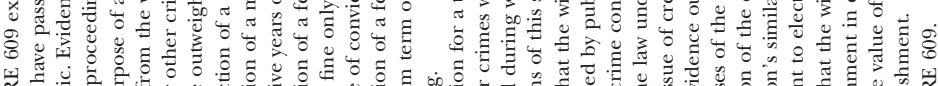

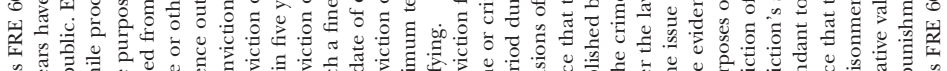

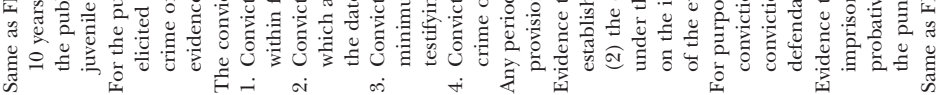

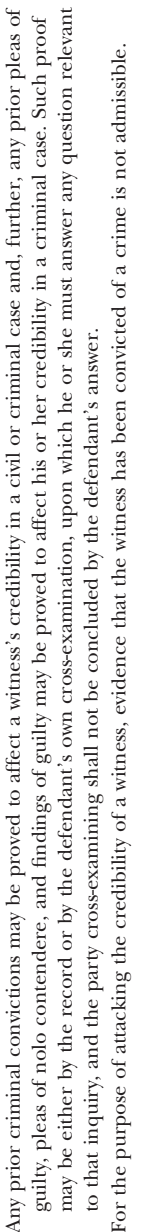

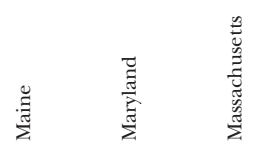

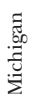

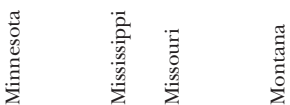




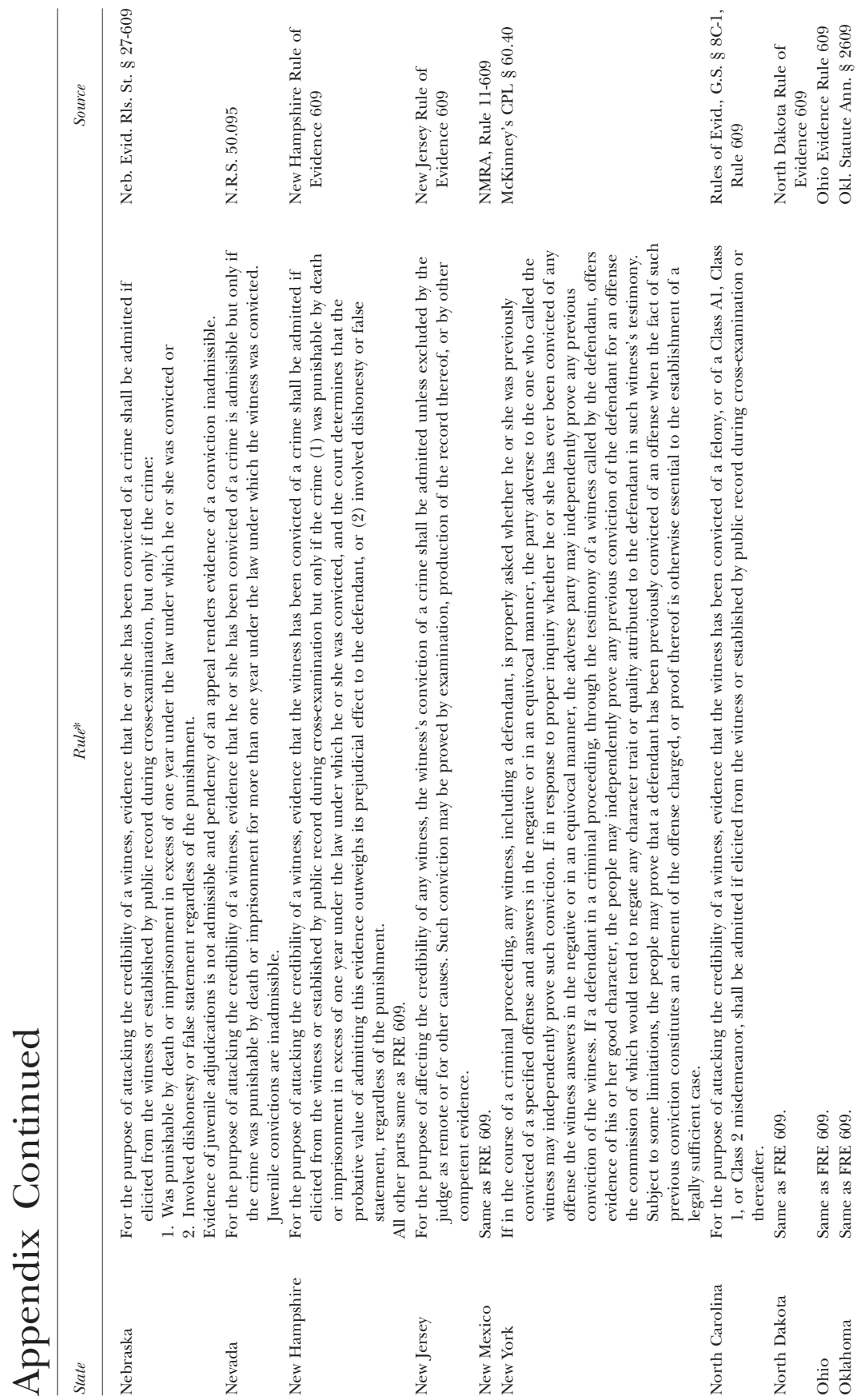



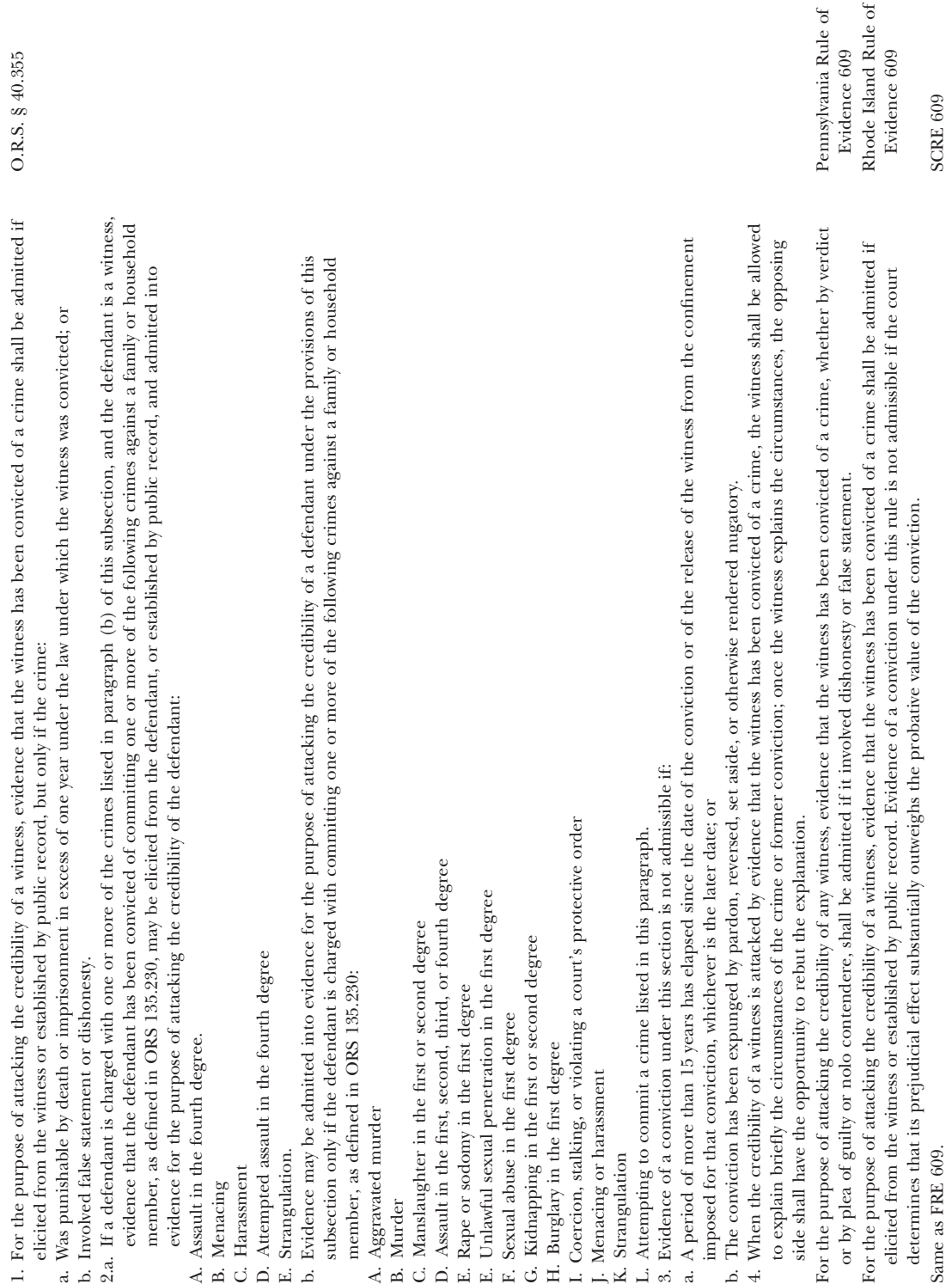


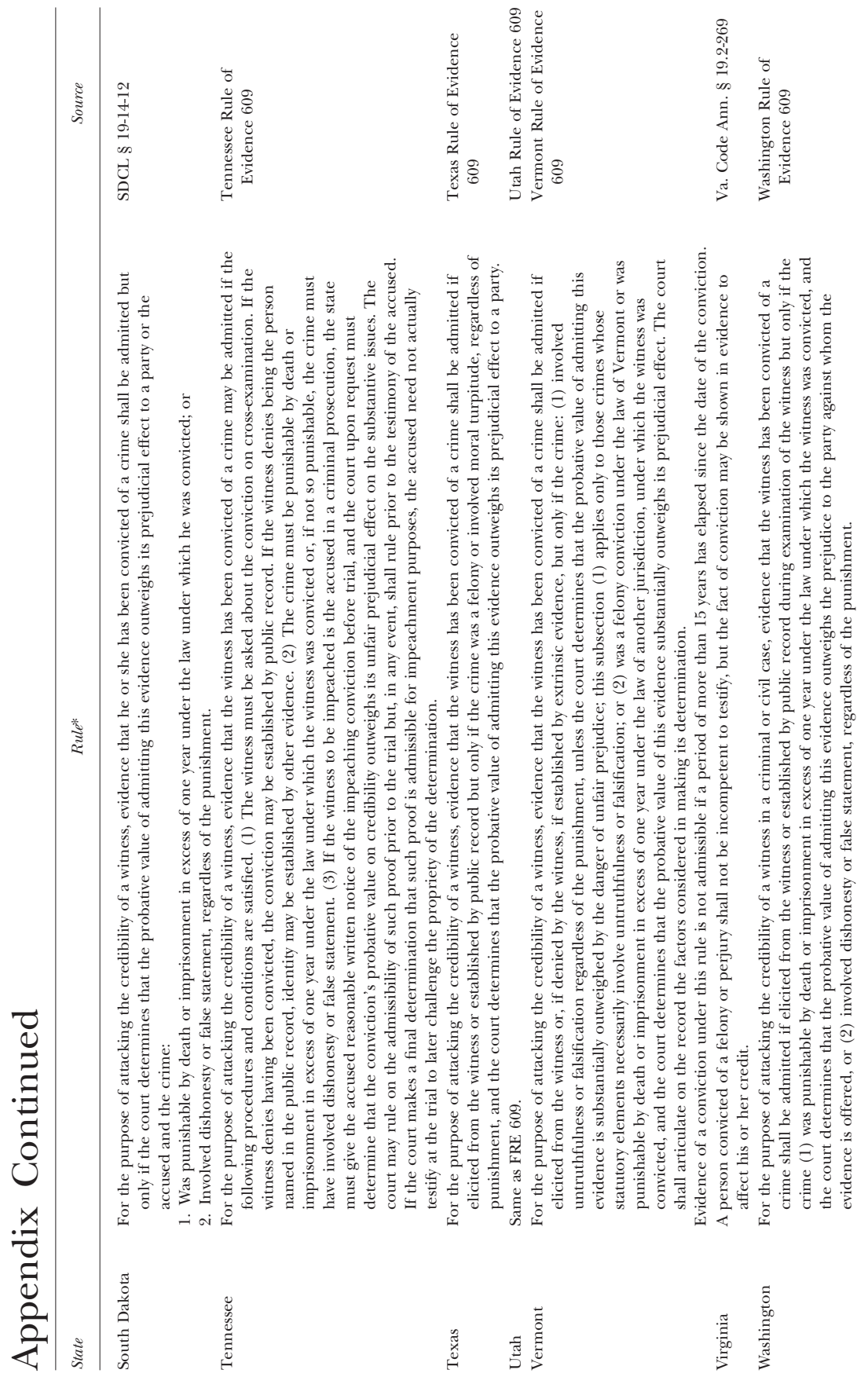


